\title{
Effect of yessotoxin on cytosolic calcium levels in human hepatocellular carcinoma cells in vitro
}

\author{
MIN PANG $^{1}$, PEI QU ${ }^{2}$, CHUN-LEI GAO $^{1}$, XUEXI TANG $^{2}$ and ZONG-LING WANG ${ }^{1}$ \\ ${ }^{1}$ First Institute of Oceanography, State Oceanic Administration, Qingdao, Shandong 266061; \\ ${ }^{2}$ College of Marine Life Science, Ocean University of China, Qingdao, Shandong 266100, P.R. China
}

Received October 18, 2013; Accepted November 05, 2013

DOI: $10.3892 /$ br.2013.202

\begin{abstract}
Yessotoxin (YTX) and its analogs are a type of marine toxins found in marine environments in numerous coastal countries. These toxins tend to accumulate in filter-feeding molluscs and may threaten the shellfish industry and public health. Several previous studies indicated that YTX may induce apoptosis in different types of cell lines, although the exact underlying mechanisms have not yet been elucidated. The aim of this study was to mainly focus on the effect of YTX on cytosolic $\mathrm{Ca}^{2+}$ levels in human hepatocellular carcinoma cells. In order to investigate the exact mechanism of YTX-evoked $\mathrm{Ca}^{2+}$ increase, laser scanning confocal microscopy was used, with the addition of the chelator ethylene glycol tetraacetic acid (EGTA) and nifedipine, an L-type $\mathrm{Ca}^{2+}$ channel blocker, to the reaction system. The results demonstrated that YTX caused cytosolic $\mathrm{Ca}^{2+}$ level increase in Bel7402 cells and the YTX-evoked $\mathrm{Ca}^{2+}$ increase was successfully blocked by EGTA and nifedipine. Therefore, our results indicated that YTX may cause apoptosis via inducing $\mathrm{Ca}^{2+}$ entry in Bel7402 cells.
\end{abstract}

\section{Introduction}

Yessotoxin (YTX) and its analogs are a group of lipophilic marine toxins mainly produced by the dinoflagellates Protoceratium reticulatum, Gonyaulax spinifera and Lingulodinium polyedrum. These toxins tend to accumulate in filter-feeding molluscs, have been found in numerous countries worldwide (1-6) and were first detected in shellfish samples collected from Chinese coastal areas in 2009 (7).

Correspondence to: Dr Min Pang, First Institute of Oceanography, State Oceanic Administration, 6 Xianxialing Road, Laoshan, Qingdao, Shandong 266061, P.R. China

E-mail:pm_cat@hotmail.com

Abbrevations: AM, acetoxymethyl ester; DSP, diarrheic shellfish poisoning; FACS, fluorescent-activated cell sorting; HBSS, Hanks' balanced salt solution; LSCM, laser scanning confocal microscopy; NRC, National Research Council; YTX, yessotoxin

Key words: yessotoxin, toxicity, Bel7402 human hepatocellular carcinoma cells, $\mathrm{Ca}^{2+}$ level
YTX and its analogs were first isolated from Patinopecten yessoensis in Japan (8) and were long classified as one of the categories of diarrheic shellfish poisoning (DSP) toxins (9). However, as these toxins cannot induce diarrhea, nor inhibit protein phosphatase $2 \mathrm{~A}$, like other DSP toxins, they were classified as an independent group by the European Union Commission in 2002 (10).

Apoptosis is a programmed form of cell suicide. The process of apoptosis is controlled by genes and is crucial in disease outbreaks, including cancer. Once the signaling pathway of apoptosis is activated, the process cannot be easily undergone, even by tumor cells. Thus, there is an increasing number of studies on tumor cell apoptosis, with the aim to design an effective cancer treatment (11-13). Several studies indicated that YTX may induce apoptosis in different types of cell lines (14-21). However, the exact underlying mechanisms have not been elucidated.

As the chemical structure of YTX is similar to that of brevetoxins and ciguatoxins, which were shown to interfere with voltage-gated sodium channels, the effects of YTX on transmembrane ion channels were previously investigated $(22,23)$. The present study mainly investigated the YTX-induced alterations in intracellular $\mathrm{Ca}^{2+}$ levels in Bel7402 human hepatocellular carcinoma cells and the possible underlying mechanisms.

\section{Materials and methods}

Reagents. Pure YTX was purchased from the National Research Council (NRC; Ottawa, ON, Canada). Fluo-3 acetoxymethyl ester (AM) solution $(5 \mathrm{mM})$ was purchased from Beyotime Institute of Biotechnology (Shanghai, China). Nifedipine was purchased from Sigma (St. Louis, MO, USA) and was dissolved in dimethyl sulfoxide (Merck KGaA, Darmstadt, Germany). All other chemicals were of analytical reagent grade or higher purity.

The Hanks' balanced salt solution (HBSS) used for cell washing consisted of $137 \mathrm{mM} \mathrm{NaCl}, 5.6 \mathrm{mM} \mathrm{KCl}$, $1.26 \mathrm{mM} \mathrm{CaCl}_{2}, 0.81 \mathrm{mM} \mathrm{MgSO}{ }_{4}, 0.38 \mathrm{mM} \mathrm{Na}_{2} \mathrm{HPO}_{4}$, $0.44 \mathrm{mM} \mathrm{KH}_{2} \mathrm{PO}_{4}$ and $4.2 \mathrm{mM} \mathrm{NaHCO}_{3}$. The $\mathrm{pH}$ of the HBSS was adjusted to 7.4 with $0.1 \mathrm{M} \mathrm{HCl}$ and $\mathrm{NaOH}$.

Cell culture. The Bel7402 human hepatocellular carcinoma cell line was purchased from the Cell Bank of the Shanghai 


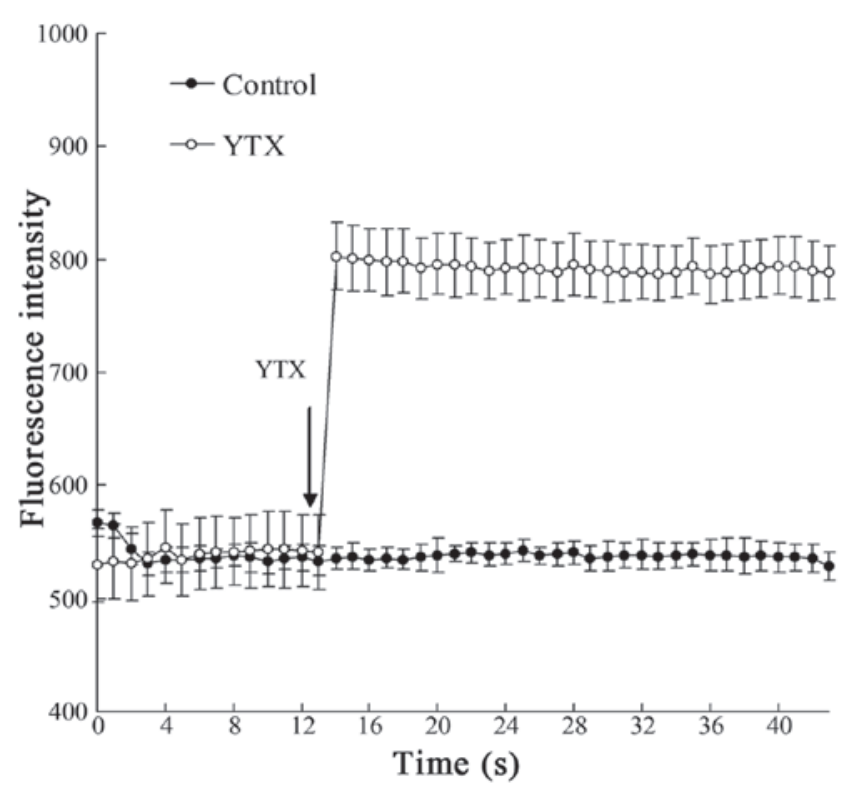

Figure 1. Effect of yessotoxin (YTX) on the $\mathrm{Ca}^{2+}$ levels in Bel7402 human hepatocellular carcinoma cells, compared to the control group. The attached Bel7402 cells in a 24-well microplate were loaded with Fluo-3 AM and bathed in a balanced salt solution containing $1 \mathrm{mM} \mathrm{CaCl}_{2}$. At the time point indicated by the arrow, $100 \mathrm{ng}$ YTX were added to the bathing medium.

Institute of Biochemistry and Cell Biology, Chinese Academy of Sciences (Shanghai, China). The cells were cultured in RPMI-1640 medium (Gibco, Carlsbad, CA, USA) supplemented with $300 \mathrm{mg} / \mathrm{l} \mathrm{L}$-glutamine, $100 \mu \mathrm{g} / \mathrm{ml}$ streptomycin and $100 \mathrm{U} / \mathrm{ml}$ penicillin, plus $10 \%$ fetal calf serum (TBD, Beijing, China) and incubated at $37^{\circ} \mathrm{C}$ in a humidified $5 \% \mathrm{CO}_{2}$ atmosphere.

Analysis of intracellular $\mathrm{Ca}^{2+}$ levels. The Bel7402 cells were transferred to a 24 -well microplate and incubated at $37^{\circ} \mathrm{C}$. When $90 \%$ confluence was reached, the cells were washed twice with HBSS and loaded with Fluo-3 AM at a final concentration of $5 \mu \mathrm{M}$ for $1 \mathrm{~h}$ at $37^{\circ} \mathrm{C}$ in the dark. The solution containing the dye was then removed and the cells were washed twice with HBSS.

The average fluorescence intensity of intracellular $\mathrm{Ca}^{2+}$ concentration in labeled cells was detected under a laser scanning confocal microscope (FluoView FV1000; Olympus Co., Tokyo, Japan). The wavelength of excitation was set at $488 \mathrm{~nm}$ and the emission wavelength at $525 \mathrm{~nm}$ for Fluo-3 fluorescence reading. Newly-developed FV300/FV500 Application software was used for the measurement and analysis of $\mathrm{Ca}^{2+}$ concentration.

Ethylene glycol tetraacetic acid (EGTA) and nifedipine, at a final concentration of $2 \mathrm{mM}$ and $1 \mu \mathrm{M}$, respectively, were added to the reaction system to investigate the exact mechanism of YTX-evoked $\mathrm{Ca}^{2+}$ increase.

\section{Results}

Effect of YTX on intracellular $\mathrm{Ca}^{2+}$ levels. As shown in Fig. 1, the intracellular $\mathrm{Ca}^{2+}$ levels in Bel7402 cells were obviously increased following the addition of YTX to the medium, with the increase of $\mathrm{Ca}^{2+}$ levels lasting for $>40 \mathrm{sec}$.

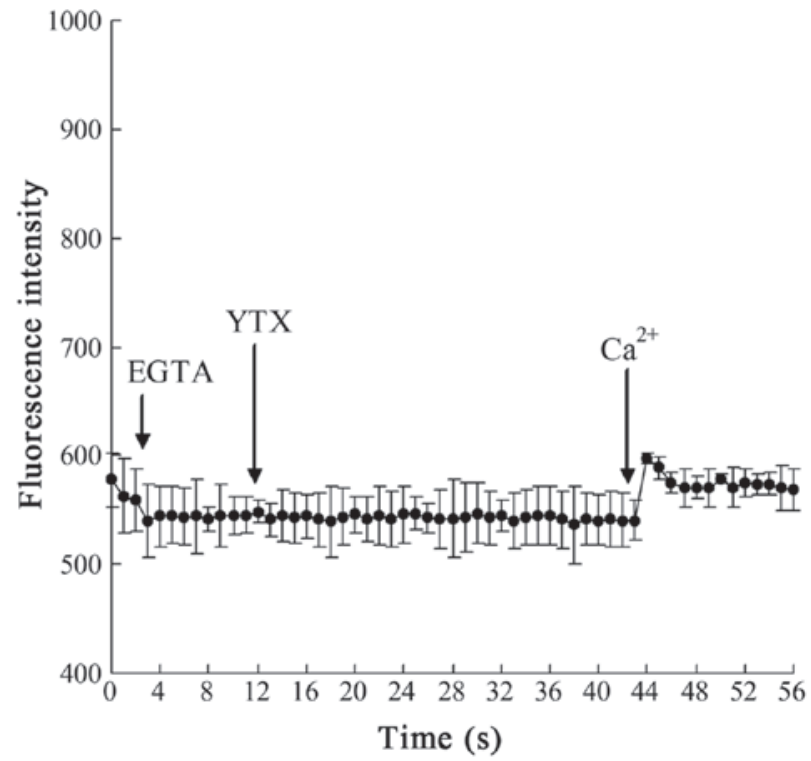

Figure 2. Effect of yessotoxin (YTX) on Bel7402 cells in a solution without $\mathrm{Ca}^{2+}$. The attached cells in the microplate were loaded with Fluo-3 AM. Susequently, the $\mathrm{Ca}^{2+}$ in the extracellular medium was removed using EGTA (indicated by the first arrow). YTX (100 ng) was then added to the medium. There was no observed increase of $\mathrm{Ca}^{2+}$ levels in the cells. Approximately $30 \mathrm{sec}$ later, $\mathrm{CaCl}_{2}$ at a final concentration of $2 \mathrm{mM}$ was added to the medium, with no resulting rise in $\mathrm{Ca}^{2+}$ levels. EGTA, ethylene glycol tetraacetic acid.

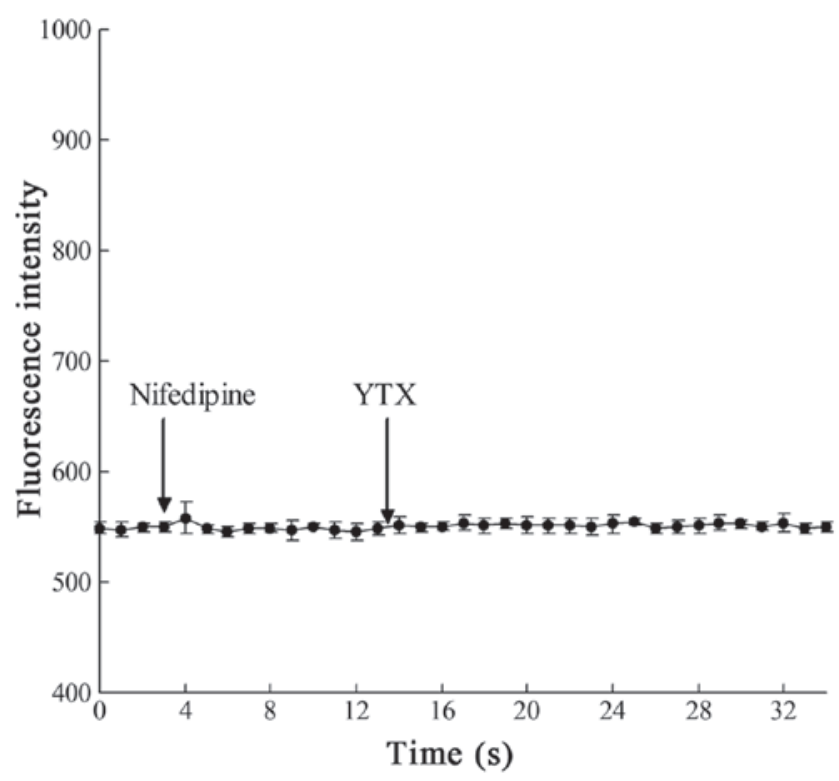

Figure 3. Effect of nifedipine on yessotoxin (YTX)-induced $\mathrm{Ca}^{2+}$ concentration elevation. Nifedipine is a well-known effective blocker of L-type $\mathrm{Ca}^{2+}$ channels. Following addition of nifedipine, YTX was added to the extracellular medium, with no resulting increase in the $\mathrm{Ca}^{2+}$ concentration.

Addition of EGTA. EGTA at a final concentration of $2 \mathrm{mM}$ was used to investigate whether the YTX-evoked $\mathrm{Ca}^{2+}$ increase was caused by $\mathrm{Ca}^{2+}$ in the extracellular medium or released from cytoplasmic organoids. As shown in Fig. 2, in $\mathrm{a} \mathrm{Ca}^{2+}$-free solution, YTX was not able to induce an elevation of the $\mathrm{Ca}^{2+}$ concentration. Although $2 \mathrm{mM} \mathrm{CaCl}_{2}$ was then added to the medium, the fluctuation of Fluo-3 fluorescence was marginal. 
Addition of nifedipine. The possible involvement of $\mathrm{Ca}^{2+}$ channels in the elevation of $\mathrm{Ca}^{2+}$ concentration evoked by YTX was also investigated. Several drugs are known to block different types of $\mathrm{Ca}^{2+}$ channels. Nifedipine, at a final concentration of $1 \mu \mathrm{M}$, was used in this study to block the L-type $\mathrm{Ca}^{2+}$ channels; YTX was then added to observe the fluorescence change in the Bel7402 cells. As shown in Fig. 3, the YTX-evoked Ca ${ }^{2+}$ increase was completely blocked by nifedipine.

\section{Discussion}

YTX is a low-molecular weight compound that is toxic to different mammalian and insect cell types, including cancer cells $(14,15,23-26)$. Our previous studies demonstrated the apoptosis induced by YTX in HeLa human cervical cancer cells, Bel7402 human hepatocellular carcinoma cells and HL7702 human liver cells (19-21). The identification of cell death signalling pathways and cellular factors involved in apoptosis induced by YTX may provide useful information for evaluating the potential use of YTX for therapeutic purposes, including cancer research. Botana Lopez et al (27) indicated that YTX may be used as an antitumor agent, with this possibility already considered in the European patent application EP1875906.

Apoptosis, the process of programmed cell death, is often characterized by an orderly progression of morphological changes, including cell shrinkage, condensation of chromatin and externalization of membrane phosphatidylserine, and is controlled by cell signals that may originate extracellularly or intracellularly (28). These signals may positively or negatively affect apoptosis. Extracellular signals, including toxins, hormones, growth factors, nitric oxide and cytokines (29), may either cross the plasma membrane or transduce into intracellular signals in order to affect other responses. $\mathrm{Ca}^{2+}$ is an important intracellular second messenger which is crucial in numerous processes, including cell proliferation, differentiation, DNA damage and apoptosis $(30,31)$. Thus, the changes in the cytoplasmic $\mathrm{Ca}^{2+}$ concentration may induce the process of apoptosis $(32,33)$. Previous studies indicated that YTX may induce the increase of $\mathrm{Ca}^{2+}$ levels in several types of cells $(22,23,26)$. Our previous studies also demonstrated that YTX may induce $\mathrm{Ca}^{2+}$ entry in different types of human cells $(21,34) . \mathrm{Ca}^{2+}$ ions are crucial in the process of apoptosis and cytoplasmic $\mathrm{Ca}^{2+}$ concentration is involved in the modulation of several cell functions. It was previously suggested that the capacitative $\mathrm{Ca}^{2+}$ influx through $\mathrm{Ca}^{2+}$ channels and the $\mathrm{Ca}^{2+}$ released in cytoplasm from intracellular organelles are apoptogenic (35-37). As described by Putney $(38,39)$, the release of $\mathrm{Ca}^{2+}$ from intercellular stores may induce $\mathrm{Ca}^{2+}$ influx from the extracellular medium. However, de la Rosa et al (22) demonstrated that the $\mathrm{Ca}^{2+}$ influx induced by YTX was not affected by internal stores. Our previous study also indicated that YTX did not affect internal $\mathrm{Ca}^{2+}$ levels in a $\mathrm{Ca}^{2+}$-free medium (21).

Although the changes in the $\mathrm{Ca}^{2+}$ levels may be associated with the apoptosis induced by YTX, the exact mechanism underlying this increase in $\mathrm{Ca}^{2+}$ has not been elucidated. The chemical structure of YTX is similar to that of brevetoxins, which are known to interfere with sodium channel function. Therefore, it is possible that YTX is also able to interact with cellular ion channels. We previously demonstrated that nifedipine, a specific
L-type $\mathrm{Ca}^{2+}$ channel blocker, was able to inhibit the $\mathrm{Ca}^{2+}$ increase induced by YTX in several human cell lines $(21,34)$. YTX may exert an effect on L-type $\mathrm{Ca}^{2+}$ channel in cells. Although YTX may induce the $\mathrm{Ca}^{2+}$ increase in HL7702 normal human liver cells and Bel7402 human hepatocellular carcinoma cells, the increasing trend of $\mathrm{Ca}^{2+}$ levels in Bel7402 cells was different from that observed in HL7702 cells (34). This difference may provide new insight into cancer therapy. Further studies are required to elucidate the exact mechanisms underlying apoptosis induced by YTX in tumor cells.

In conclusion, YTX was shown to exert a cytotoxic effect on normal human liver cells and human hepatocellular carcinoma cells. Although YTX may induce $\mathrm{Ca}^{2+}$ influx in these two cell types, the detailed increasing trend of $\mathrm{Ca}^{2+}$ levels was different. The difference between normal human liver cells and human hepatocellular carcinoma cells may provide new insight into cancer therapy.

\section{Acknowledgements}

This study was supported by the Fundamental Science Research Project of FIO (no. 2011T07), the youth fund of State Oceanic Administration (no. 2012123) and project of the Key Laboratory for Ecological Environment in Coastal Areas, SOA (no. 201106).

\section{References}

1. Satake M, MacKenzie L and Yasumoto T: Identification of Protoceratium reticulatum as the biogenetic origin of yessotoxin. Nat Toxins 5: 164-167, 1997.

2. Draisci R, Ferretti E, Palleschi L, et al: High levels of yessotoxin in mussels and presence of yessotoxin and homoyessotoxin in dinoflagellates of the Adriatic Sea. Toxicon 37: 1187-1193, 1999.

3. Stobo LA, Lewis J, Quilliam MA, et al: Detection of yessotoxin in UK and Canadian isolates of phytoplankton and optimization and validation of LC-MS methods. In: Proceedings of the Eighth Canadian Workshop on Harmful Marine Algae. Bates S (ed). Can Tech Rep Fish Aquat Sci, Gulf Fisheries Centre, Moncton, pp8-14, 2003.

4. Ciminiello P, Dell'Aversano C, Fattorusso E, et al: Complex yessotoxins profile in Protoceratium reticulatum from northwestern Adriatic sea revealed by LC-MS analysis. Toxicon 42: 7-14, 2003 (In Chinese).

5. Arévalo F, Pazos Y, Correa J, Salgado C, Moroño A, Paz B and Franco JM: First report of yessotoxins in mussels of Galician Rías during a bloom of Lingulodinium polyedra Stein (Dodge). In: Henshilwood K, Deegan B, McMahon T, Cusack C, Keaveney S, Silke J, O'Cinneide M, Lyons D and Hess P (eds). Galway, pp184-189, 2006.

6. Morton SL, Vershinin A, Leighfield TA, Smith L and Quilliam M: Identification of yessotoxin in mussels from the Caucasian Black Sea Coast of the Russian Federation. Toxicon 50: 581-584, 2007.

7. Gao CL, Liu RY, Liang YB, et al: First report of the presence of yessotoxins (YTXs) in shellfish from China's coastal areas. Acta Oceanol Sin 3: 129-137, 2010.

8. Murata M, Masanori K, Lee JS and Yasumoto T: Isolation and structure of yessotoxin, a novel polyether compound implicated in diarrhetic shellfish poisoning. Tetrahedron Lett 28: 5869-5872, 1987.

9. Yasumoto T and Takizawa A: Fluorometric measurement of yessotoxins in shellfish by high-pressure liquid chromatography. Biosci Biotechnol Biochem 61: 1775-1777, 1997.

10. 2002/225/EC: Commission Decision of 15 March 2002 laying down detailed rules for the implementation of Council Directive 91/492/EEC as regards the maximum levels and the methods of analysis of certain marine biotoxins in bivalve molluscs, echinoderms, tunicates and marine gastropods. Official Journal of the European Communities, pp62, 2002.

11. Green DR and Reed JC: Mitochondria and apoptosis. Science 281: 1309-1312, 1998. 
12. Green DR and Evan GI: A matter of life and death. Cancer Cell 1:19-30, 2002.

13. Green DR and Kroemer G: The pathophysiology of mitochondrial cell death. Science 305: 626-629, 2004.

14. Malagutia C, Ciminiellob P, Fattorussob E and Rossinia GP: Caspase activation and death induced by yessotoxin in HeLa cells. Toxicol In Vitro 16: 357-363, 2002.

15. Leira F, Alvarez C, Vieites JM, Vieytes MR and Botana LM: Characterization of distinct apoptotic changes induced by okadaic acid and yessotoxin in the BE(2)-M17 neuroblastoma cell line. Toxicol In Vitro 16: 23-31, 2002.

16. Suárez Korsnes M, Hetland DL, Espenes A and Aune T: Induction of apoptosis by YTX in myoblast cell lines via mitochondrial signalling transduction pathway. Toxicol In Vitro 20: 1419-1426, 2006.

17. Suárez Korsnes M, Hetland DL, Espenes A, Tranulis MA and Aune T: Apoptotic events induced by yessotoxin in myoblast cel lines from rat and mouse. Toxicol In Vitro 20: 1077-1087, 2006.

18. Suárez Korsnes M,Hetland DL, Espenes A and Aune T: Cleavage of tensin during cytoskeleton disruption in YTX-induced apoptosis. Toxicol In Vitro 21: 9-15, 2007.

19. Pang M, Gao CL, Wu ZX, Lv N, Wang ZL, Tang XX and Qu P Apoptosis induced by yessotoxins in HeLa human cervical cancer cells in vitro. Mol Med Rep 3: 629-634, 2010.

20. Pang M, Wang ZL, Gao CL, Qu P and Li HD: Characterization of apoptotic changes induced by yessotoxin in the Bel7402 human hepatoma cell line. Mol Med Rep 4: 547-552, 2011.

21. Pang M, Qu P, Gao CL and Wang ZL: Yessotoxin induces apoptosis in HL7702 human liver cells. Mol Med Rep 5: 211-216, 2012.

22. de la Rosa LA, Alfonso A, Vilarino N, Vieytes MR and Botana LM: Modulation of cytosolic calcium levels of human lymphocytes by yessotoxin, a novel marine phycotoxin. Biochem Pharmacol 61: 827-833, 2001.

23. Perez-Gomez A, Fererro-Gutierrez A, Novelli A, Franco JM, Paz B and Fernandez-Sanchez MT: Potent neurotoxic action of the shellfish biotoxin yessotoxin on cultured cerebellar neurons. Toxicol Sci 90: 168-177, 2006.

24. Korsnes MS, Hetland DL, Espenes A and Aune T: Induction of apoptosis by YTX in myoblast cell lines via mitochondrial signalling transduction pathway. Toxicol In Vitro 20: 1419-1426, 2006.

25. Korsnes MS, Hetland DL, Espenes A, Tranulis MA and Aune T: Apoptotic events induced by yessotoxin in myoblast cell lines from rat and mouse. Toxicol In Vitro 20: 1077-1087, 2006.

26. Malagoli D, Marchesini E and Ottaviani E: Lysosomes as the target of yessotoxin in invertebrate and vertebrate cell lines. Toxicol Lett 167: 75-83, 2006.
27. Botana Lopez LM, Alfonso Rancano A, Rodriguez Vieytes M and Loza Garcia MI: Therapeutic use of yessotoxins as human tumor cell growth inhibitors. EP 1875906 B1. Filed July 21, 2004; issued June 29, 2011.

28. Martin SJ, Reutelingsperger CP, McGahon AJ, Rader JA, van Schie RC, LaFace DM and Green DR: Early redistribution of plasma membrane phosphatidylserines is a general feature of apoptosis regardless of the initiating stimulus: inhibition by overexpression of Bcl-2 and Abl. J Exp Med 182: 1545-1556, 1995.

29. Popov SG, Villasmil R, Bernardi J, et al: Lethal toxin of Bacillus anthracis causes apoptosis of macrophages. Biochem Bioph Res Commun 293: 349-355, 2002.

30. Berridge MJ, Lipp P and Bootman MD: The versatility and universality of calcium signalling. Nat Rev Mol Cell Biol 1: 11-21, 2000.

31. Mattson MP and Chan SL: Calcium orchestrates apoptosis. Nat Cell Biol 5: 1041-1043, 2003.

32. Ferrari D, Pinton P, Szabadkai G, Chami M, Campanella M, Pozzan T and Rizzuto R: Endoplasmic reticulum, Bcl-2 and $\mathrm{Ca}^{2+}$ handling in apoptosis. Cell Calcium 32: 413-420, 2002.

33. Smaili SS, Hsu YT, Carvalho ACP, Rosenstock TR, Sharpe JC and Youle RJ: Mitochondria, calcium and pro-apoptotic proteins as mediators in cell death signaling. Braz J Med Biol Res 36: 183-190, 2003

34. Pang M, Qu P, Gao CL, Wang ZL and Zhang Y: Apoptosis and intracellular calcium level change induced by yessotoxin in $\mathrm{HeLa}$ cells. J Fish China 35: 1729-1735, 2011.

35. Jiang S, Chow SC, Nicotera P and Orrenius S: Intracellular $\mathrm{Ca}^{2+}$ signals activate apoptosis in thymocytes: studies using the $\mathrm{Ca}^{2+}$-ATPase inhibitor thapsigargin. Exp Cell Res 212: 84-92, 1994.

36. Wertz IE and Dixit VM: Characterization of calcium release-activated apoptosis of LNCaP prostate cancer cells. J Biol Chem 275: 11470-11477, 2000

37. Pinton P, Ferrari D, Rapizzi E, Di Virgilio F, Pozzan T and Rizzuto R: The $\mathrm{Ca}^{2+}$ concentration of the endoplasmic reticulum is a key determinant of ceramide-induced apoptosis: significance for the molecular mechanism of Bcl-2 action. EMBO J 20: 2690-2701, 2001.

38. Putney JW Jr: Receptor-regulated calcium entry. Pharmacol Ther 48: 427-434, 1990.

39. Putney JW Jr: Capacitative calcium entry revisited: Review article. Cell Calcium 11: 611-624, 1990. 